\title{
The Simulation Utilization for the Bottleneck Identification
}

\section{Summary}

Advancing globalization increasingly leads to the creation of delivery systems. Increasing competition forces companies to reduce costs permanently. Both of these trends lead to the need to control material and information flows precisely. The target of this article is to describe and show one of ways of bottleneck determination in the supply system. This study deals with the computer simulation and its utilization for assessment of bottleneck. The foundation of the work is created a model of the supply system, it is used to compare the costs associated with the existence of stocks and stock levels in the individual partner of the system, depending on the location of the bottleneck. This article is published as a part of the research intention MSM 6046137306.

\section{Introduction}

At the end of the 20th century, many businesses in the market found themselves in an entirely new situation, which had to be able to cope; otherwise their business would soon be over. Newly applied technologies and information technologies have affected the emergence of a range of new products, the method of implementation and sales. At the same time habits and needs of final customers were changed. Therefore - in recent years for the effective management of material flows in the enterprise and better meet customer needs - to the forefront comes a method based on the Theory of Constraints, finding bottlenecks. If you connect the fact that the development is currently very fast, product life cycles are becoming shorter and there is a globalization of the market, it is not surprising

${ }^{*}$ MSc., Department of Economics and Management of Chemical and Food Industry, Institute of Chemical Technology, Prague, Czech Republic. 
that the concept of Theory of Constraints was gradually extended to the entire logistics and subsequently the whole supply system. Today it is not enough only good map and manage material and information flows in their business, but it should be managed them in relation to other articles of the supply system. Only thus it can become more competitive as an integrated part of a complex system.

One method to establish the close location of the production line, company or the entire supply system is the computer simulation. This concept is gradually gaining prominence, because simulations solve large number problems in the system. On this basis, the simulation began to make greater use in enterprises.

\section{Theory of Constrains}

Theory of Constrains (TOC) is a managerial philosophy, formulated by Goldratt (1999). One of the basic ideas of this theory is that each company or any logistics and supply chain contains one or more restrictions, which affect the overall operation of the real system. Therefore it can be said that each department or production stage in the company or any link in the chain is limited by the weakest and must adapt to restrictive article. At the same time you do have not to forget to fulfill the basic objectives of the company - a profit in the long term through satisfying customer needs.

Basl, Majer and Šmíra (2003) state that it is customary to measure the success and effectiveness of enterprise by the help of basic financial indicators. The basic financial indicators include the value of the net profit is derived from a profit and loss report. The second indicator is the basic financial ratio representing the return on investment (ROI), whose treatment is the financial statements balance sheet, profit and loss report and statement of cash flow. Goldratt believes that these financial indicators understand business owners and business management only. Their clarity is gradually decreasing towards the lower level of management and the ultimate executive staff. But a good knowledge of business objectives and the ability to meet the everyday decisions, and do so all employees are among the basic conditions for a successful company. For these reasons TOC defines its own operating parameters - flow, stocks and operating costs:

- Flow - the rate at which the system generates money through sales. Flow means a financial statement exit string provides. Flow is limited by a bottleneck, which may be internal (eg. a production capacity of the device) or external (eg. customer requirements). Flow-chain can be increased only by increasing the capacity bottleneck.

- Stocks - represents all the money they put into the purchase of the system of things which it intends to sell. It is therefore an expression of all financial stocks between input and output point chain.

- Operating costs - means all the money spent by the system that inventories transformed into flow.

The operation parameters - if their values move in the right direction, then the enterprise will certainly fulfilled its main goal - to earn money. It is therefore to increase the flow, when the company sells more products to maintain a constant level of inventory 
and operating costs. Increasing the flow rate directly increases the value of net profit, ROI and cash flow. The stock must be reduced in the constant flow and operating costs, which directly affects cash flow and ROI. To achieve the objectives it is necessary for there to reduce operating costs while maintaining the amount of flow and stock. This cost reduction has once again resulted in improvement of all three financial indicators. It is a simple way for all employees" immediately visible way to analyze the situation of the company (Lenort, 2007). Goldratt believes that companies should focus on improving operating parameters in this order - first and foremost seek measures to increase the flow, then to reduce inventories and to last for reducing operating costs. It builds on the assumption that reducing inventory and operating costs has its limits, but only by increasing the flow can guarantee a lasting achievement of the primary objectives of the company.

Theory of Constraints focuses attention on the bottleneck, which is known as a place of business or the supply chain with the lowest performance. Also for bottleneck can be found in the literature a number of definitions. Bottleneck may be under the above authors characterized as follows (Lenort, 2007, Basl, Majer, Šmíra, 2003, Gros, 1996):

- a place that must be fully exploited;

- instead of making a decisive impact on the level of services;

- location, which should be placed on management of the real system;

- instead, before whom should be localized supply of work in progress to ensure its continued function;

- a place that hinders the achievement of unrestricted flow and thus unlimited financial income business;

- the element of the production process, which do not guarantee maximum production even though it is used on $100 \%$;

- a place that is the weakest link and determines the performance of your production system;

- any production element that somehow „brakes” fluency of material flow and reduces the utilization of production capacity of other elements.

If the goal is to increase system performance enterprise and the flow, it is necessary to increase the throughput (i.e. performance) of bottleneck. Any increase in the permeability of the other elements of the system will not lead to that objective. The same logic applies to the supply system. If the goal is to increase the performance of your system, it is necessary to determine which link is a bottleneck and increase its throughput.

The way to overcome the constraints (bottlenecks) is formulated into five basic steps that can help bring the system to improve performance and objectives (Goldratt, 1999).

The first step is identification of the system limitations. Internal and substantive bottlenecks in the enterprise may be very well identified and then overcome relatively easily. This may appear intangible restrictions outside the company, which is very difficult to identify and remove.

The second step is the maximum use of the restrictions. The basic idea of this step is the use of the identified bottleneck to $100 \%$.

The third step is making all the system this limitation. Bottleneck is adapted to other activities and processes. This may mean less use and reduce efficiency. 
The fourth step is the removal of restrictions. Following action often happens that the restriction goes to another part of the company or to another part of the supply system.

Finally, the fifth step - if the bottleneck is removed, the cycle is repeated from the first step.

\section{Drum - Buffer - Rope (DBR system)}

This system is based on a simple idea. The basic principle is to try to explain the company, which consists of several sites that are logically connected. The aim is to implement a requirement of the customer in the required time, in the required quantity, the required quality at the desired location at the asking price. Material flow is from receipt of material to despatch of goods to the customer. Every workplace is characterized by a certain capacity, works at different rates due to different production capacity and subjects to influences and random variations. Individual workplaces processed inputs. For reasons difference in the performance of material flow the production-in-progress are formed before individual workplaces. These stocks are ineffective locked-up capital stored and it is necessary to address the size and location of the buffers. A department with the lowest performance is called the bottleneck of the production process.

Under these conditions, there will be that all work before the bottleneck, which has the lowest production capacity will gradually gain a greater advantage in the number of semi-finished products. Thus the department will restrict the brake-up, hence the entire production process. Due to the inventory gradually progress and lead times extend. To meet the objective - to realize the requirement in time - it is necessary to resolve the capacitance problem.

One solution might be to use the principle of DBR system. This tool is based on the idea that the workplace is the first and the slowest workstation is necessary to combine the control circuit using ropes, which they close the place governing inputs, as this will limit the exercise of all the jobs tied to the performance of the slowest. Department before the bottleneck can not be distinguished, the ropenot allow them. Although all work are faster before restriction soon they adapt to a bottleneck. This will eliminate stocks developed production before each institution, and created large areas for stocks prior bottleneck. The buffer is called equalization, it would serve to compensate for the performance of all workplaces. Departments with the lowest performance of the rhythm and pace of production (the rhythm of drums), others adapt to that pace through the rope and equalization buffer.

The aim is to draw up a realistic plan that will comply with the requirements of customers on the one hand, and the bottleneck limiting the performance on the other. Bazala et al., (2003) in its publication describes factors to be taken into account when formulating plans for bottleneck in the production:

- priority in production - to determine the order of products with regard to the dates of completion of contracts according to customer demand,

- lot size - if you accumulate the various requirements of customers in the joint production of benefits, it is possible to close the place to establish so-called minimum batch size to ensure high capacity utilization, 
- size of handling and transport lot - balancing carried out between small doses of handling accelerating the flow of material production and the cost of frequent handling.

Another important point in the system is equalization buffer. This is a time buffer, which determines in advance, to which must be available prior to each semi bottleneck. Time buffer constitutes in an earlier availability of preparations ahead of the planned work on the site constraints. However, this stock does not affect the increase in stocks in the system or to extend the period of continuous production. If you create an inventory of the bottleneck, you can use this place with a maximum deployment ever, while other work will stand or be adjusted or in failure. Tray therefore creates protection against the effects of randomness so as to maximize the flow. Equalization buffer capacity depends on the frequency and duration of disturbances and variations in the workplace before the restrictions. It is necessary to consider capacity in determining the cost of maintaining stocks of buffer, ineffective locked-up capital and costs caused by losses from shortages of supplies. In practice, the capacity of buffer usually expressed in days (Lenort, 2007).

The Figure 1 is an example of the choice position bottleneck in the logistics chain in the manufacturer of the finished product. This means that before it is created by equalization stock of component produced by the plan bottleneck.

Grosová and Gros (2007) mention that in the chain of the capacity requirements arising from the need to meet specific customer orders and forecasts for the balance sheet and additional requirements compared with actual capacity. At the same time identified a bottleneck, which creates a specific plan. If the capacity meets becomes a place of place, which directly determines the course and follow up the material flow of all partners, and for his full recovery is created before store work in progress. In essence, the previous stage

Figure 1. Bottleneck - push and pull system

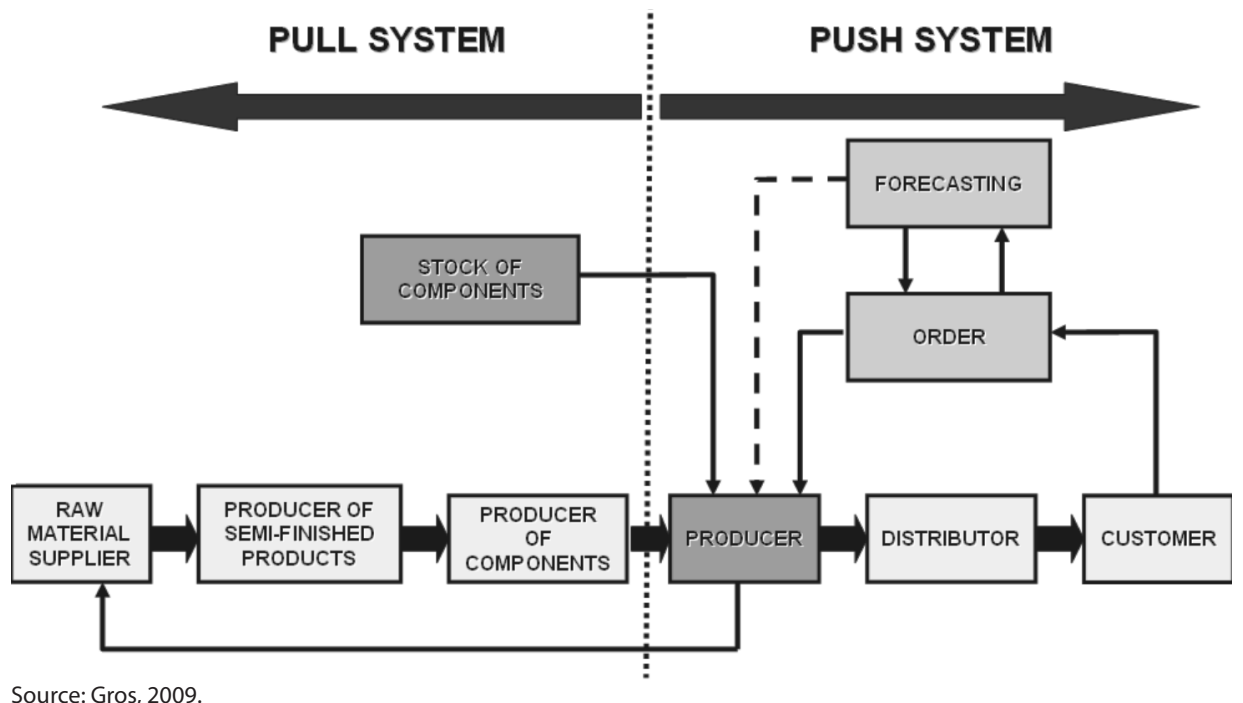


of the application of the pull system - a close place controls, as it requires the input of the previous component. Since the bottleneck is the application of the push system, because the downstream stages are higher capacity than bottleneck and broken down a plan to close instead of respecting the customer orders for the period.

\section{Computer Simulation}

In today's turbulent environment can not achieve efficient operation of production systems, only local optimization of individual parameters or subsystems. These are so interact one to another that can not be addressed in isolation, but must be seen in the whole system globally and look for optimum system as a whole. High dynamics, complexity, and thereby the uncertainty in solving business problems increasingly require the use of such methods and support resources that enable a comprehensive approach to design manufacturing systems and rapid testing of various alternative solutions, thus minimizing the risk of erroneous decisions. Important helper is therefore becoming a dynamic analysis of complex manufacturing systems using computer simulation (Manlig, Urban, 2001).

Computer simulation has thus become an extremely effective tool to overcome problems of mathematical modeling, which is currently restricted to the simple problems. Computer simulation can be characterized as a way to display the behavior of real object on the computer. Simulations are generally effective tool for solving problems of operational management of production. But they can be used also for managing production processes, for services and for strategic decision making.

Computer simulation deals with Dlouhý et al. (2007), explaining the concept as a modern tool for analyzing complex manufacturing, supply, service, communications and other business processes or systems. Simulation is a method that uses a computer model of business process allows managers to predict the behavior of changing internal and external conditions that optimize business processes in relation to specified criteria (e.g.: revenue, cost, reliability), to compare between the proposed alternatives to the organization of the studied process.

The principle of simulation is simple. Instead of watching the dynamic behavior of the process and its response by the organizational, technical or technological change, monitor the behavior of the model. Such a process can be modeled as a production line system of public service, wholesale warehouse, the flow of information in the bank branch, etc. This kind of analysis brings many benefits. Simulation time can run faster than real, and so it is possible to rapidly assess the various options proposed solutions to problems without going to hit the real analysis process. The risk of large financial losses resulting from bad decisions is because simulačnímu modeling minimized, since any error discovered in the experiments with the computer model is always cheaper than a bug that is exposed to in the implementation of specific, previously uncharted design solution. Authors with whose views I agree sees significant advantage of simulation is that everything happens only in a computer model, without the necessary intervention into business operations. 
Figure 2. Computer Simulation

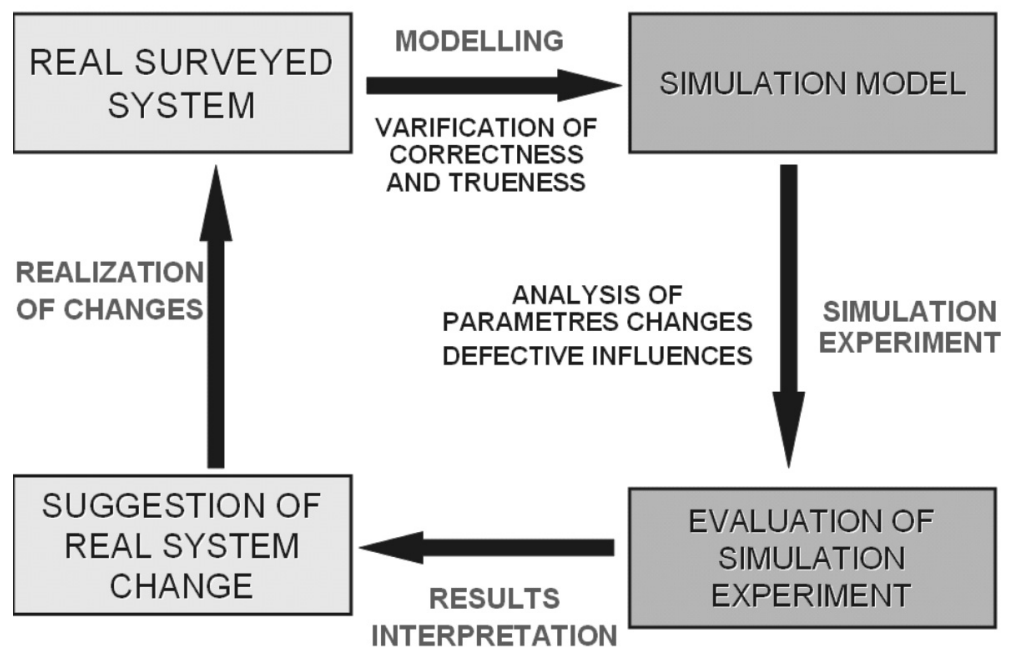

\section{Model of Supply Chain}

Identification of bottleneck I show on model of supply system that was created in environment of simulation programme Witness. Model has six degrees, it starts with final customers, continues trade network (retailers and wholesales), producers, semi-finished suppliers up to raw materials suppliers. In every degree is occurred specific number of raw materials (12), semi-finished products (8) and final products (6). It is possible to change these values. Starting point are demands of every products. Demands are generated customer's requirements by help of random-number generator in programme MS Excel ${ }^{\mathrm{TM}}$. Again it is possible to change character of demand from totally periodic to totally random. On Figure 3 you will see simplified supply system.

All needed parameters individual elements, for example cycle time of production, lead time, price of raw materials, input stock for individual warehouse, signal stock level, quantity order etc. are written into table of programme MS Excel. User can very simply change this table according to real situation. These changes are seeing promptly in model. Argument, why I used programme MS Excel, is very simply. This programme is frequently used tool for control in many companies, because it is currently available. The part of supply system you can see on Figure 4.

In simulation model it is possible to observe the influence bottleneck on stock state of individual partners in supply system. One of outputs is dynamic graphs that are illustrated stock states period under consideration. This period is possible to set at any time, for example one hour, one day, one month etc.

The second outputs are calculated total costs. These costs are separated in three parts. First section are costs stock replenishment that are dependent on number of order and costs 
Figure 3. Simplifies supply system

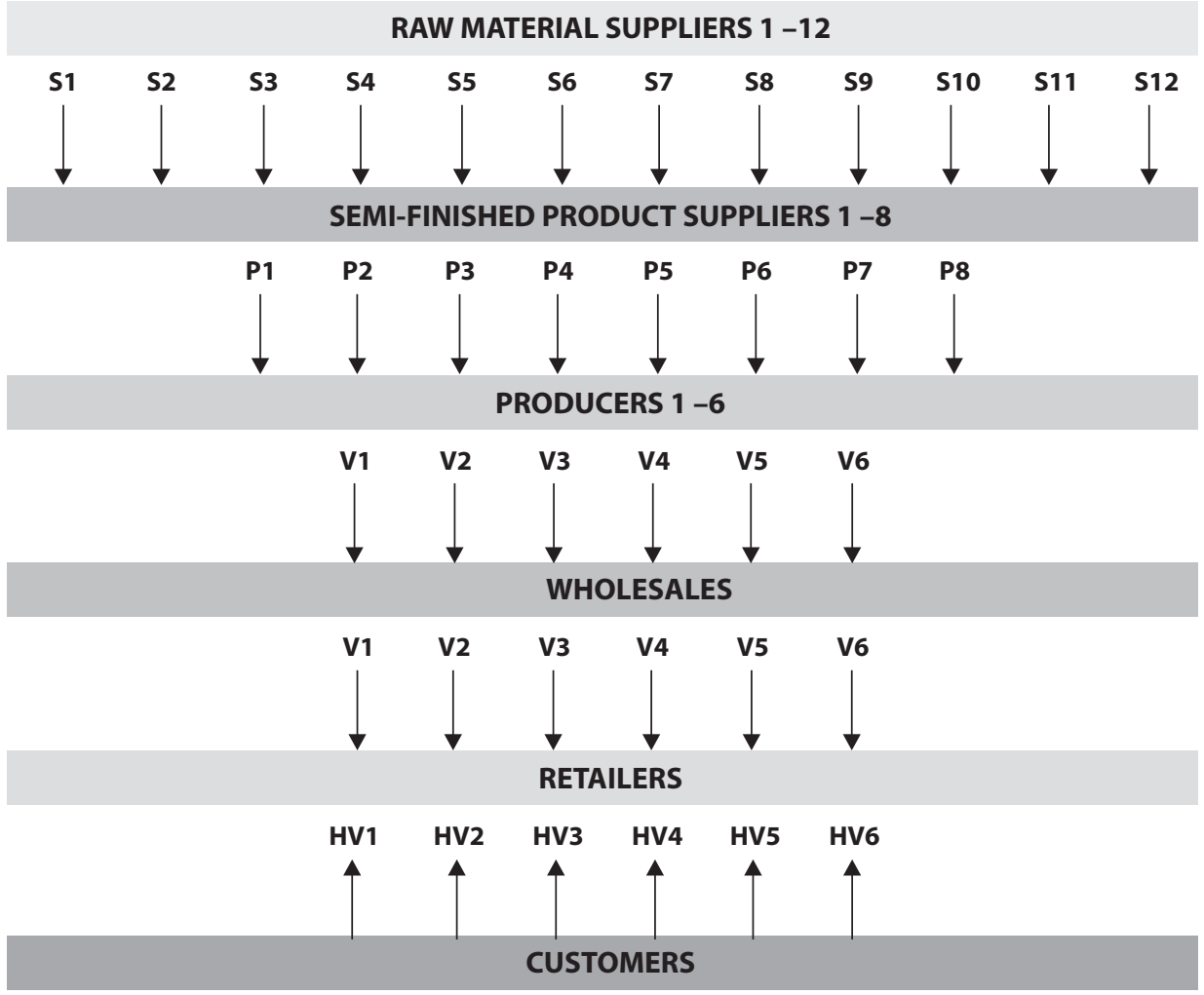

Figure 4. Part of Supply System

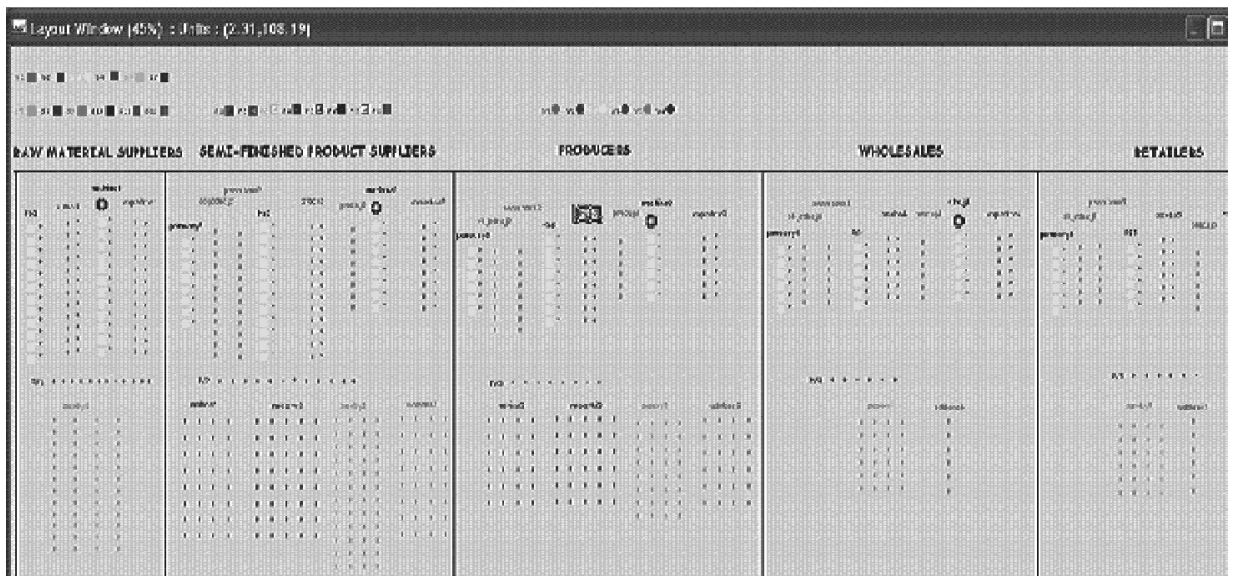


Figure 5. Chart of Utilization

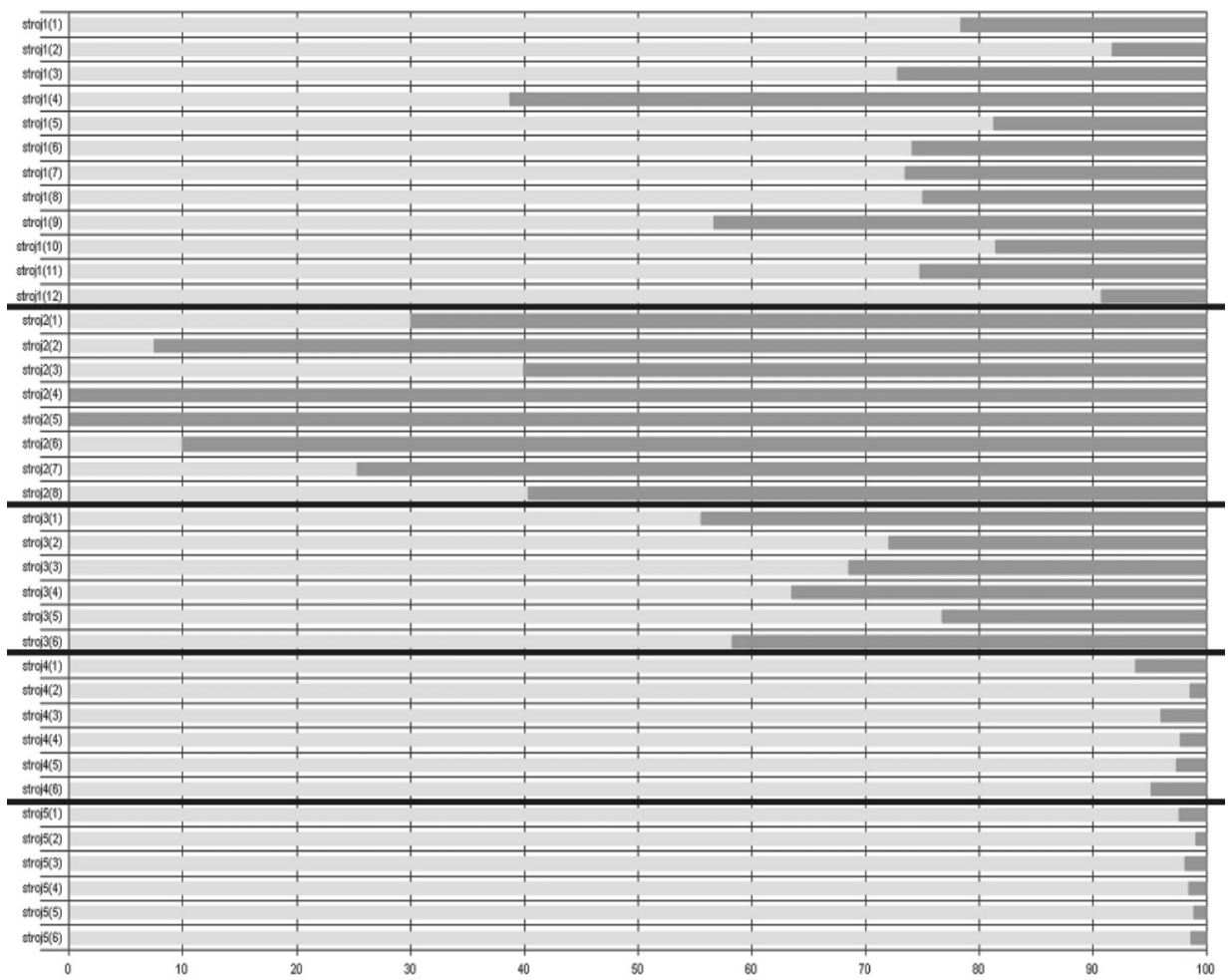

of one order. Number of order is determined by the help of variable in model, costs of one order are written into programme MS Excel ${ }^{\mathrm{TM}}$ for simply change. Second part is costs of maintenance and stocking. For determination the programme results from average stock values that are calculated by the help of chronological average. The third costs are losses from absence stock in warehouse. These values are determined by the help of variables that are observed non-customer's requirements in required time. Total costs are calculated in table of programme MS Excel ${ }^{\mathrm{TM}}$ and at the same time in simulation programme.

For determination of bottleneck in supply system it is possible to obtain the chart of utilization of machine in production (partners in system). Utilization is expressed by percent. Yellow fields describe the state „Idle” and green ones „Busy”. The chart is showed on the Figure 5.

On the Figure 5 you can see one bottleneck. In this case it is second partners in supply system: semi - finished product suppliers. Their utilization is $100 \%$, thus working to maximum power. The exact use can be determined using the table for an illustrated overview of the use case is in the table 1. 
Table 1. Statistics of supply system

\begin{tabular}{|c|c|c|c|c|c|c|c|}
\hline Partner & Idle $(\%)$ & Busy $(\%)$ & Number of Operations & Partner & Idle $(\%)$ & Busy (\%) & Number of Operations \\
\hline raw material supplier(1) & 78.33 & 21.67 & 117 & producer(1) & 55.56 & 44.44 & 64 \\
\hline raw material supplier(2) & 91.67 & 8.33 & 60 & producer(2) & 72.04 & 27.96 & 30 \\
\hline raw material supplier(3) & 72.84 & 27.16 & 176 & producer(3) & 68.52 & 31.48 & 42 \\
\hline raw material supplier(4) & 38.75 & 61.25 & 189 & producer(4) & 63.47 & 36.53 & 46 \\
\hline raw material supplier(5) & 81.25 & 18.75 & 135 & producer(5) & 76.73 & 23.27 & 35 \\
\hline raw material supplier(6) & 74.07 & 25.93 & 140 & producer(6) & 58.33 & 41.67 & 50 \\
\hline raw material supplier(7) & 73.52 & 26.48 & 143 & wholesale(1) & 93.7 & 6.3 & 68 \\
\hline raw material supplier(8) & 75 & 25 & 180 & wholesale(2) & 98.52 & 1.48 & 32 \\
\hline raw material supplier(9) & 56.71 & 43.29 & 187 & Wholesale(3) & 95.93 & 4.07 & 44 \\
\hline raw material supplier(10) & 81.48 & 18.52 & 100 & wholesale(4) & 97.69 & 2.31 & 50 \\
\hline raw material supplier(11) & 74.81 & 25.19 & 136 & wholesale(5) & 97.36 & 2.64 & 38 \\
\hline raw material supplier(12) & 90.74 & 9.26 & 40 & wholesale(6) & 95.09 & 4.91 & 53 \\
\hline semi-finished product supplier(1) & 30 & 70 & 63 & retailer(1) & 97.59 & 2.41 & 65 \\
\hline semi-finished product supplier(2) & 7.5 & 92.5 & 111 & retailer(2) & 99.03 & 0.97 & 35 \\
\hline semi-finished product supplier(3) & 39.91 & 60.09 & 59 & retailer(3) & 98.08 & 1.92 & 46 \\
\hline semi-finished product supplier(4) & 0 & 100 & 107 & retailer(4) & 98.43 & 1.57 & 51 \\
\hline semi-finished product supplier(5) & 0 & 100 & 154 & retailer(5) & 98.83 & 1.17 & 36 \\
\hline semi-finished product supplier(b) & 9.97 & 90.03 & 88 & retailer(6) & 98.58 & 1.42 & 51 \\
\hline semi-finished product supplier(7) & 25.37 & 74.63 & 62 & & & & \\
\hline semi-finished product supplier $(8)$ & 40.37 & 59.63 & 46 & & & & \\
\hline
\end{tabular}

\section{Conclusions}

Before the establishment of a bottleneck power profile is used, it is necessary to calculate the performance of each cell line or chain. Today, it is possible to determine the model used in the simulation environment created. In my article I have created a model in Witness protection program, which is used in our department. To determine the bottleneck is possible to use graphical expression or table. The advantage of computer simulation is to obtain quick results and to simple changes in the process of removing bottleneck. One way is to clone the link, re-run simulations and the subsequent deduction of the results. It can thus be concluded that the results are visible immediately. This article is published as a part of research intention MSM 6046137306.

\section{References}

Basl J., Majer P., Šmira M., Teorie omezeni v podnikové praxi. Zvyšováni výkonnosti podniku nástroji TOC, Grada Publishing a.s., Praha 2003.

Bazala J. et al., Logistika v praxi, Verlag Dashöfer, Praha 2003.

Dlouhy M. et al., Simulace podnikových procesü, Computer Press a.s., Brno 2007.

Goldrate E.M., Cox J., Cíl, InterQuanlity s.r.o., Praha 1999.

Gros I., Logistika, VŠCHT Praha, 1996.

Gros I., Grosova S., Demain chain new term or new approach in customers needs meeting?, Research Papers, 2007, 3 (2).

Lenort R., Teorie omezení. Systém DBR, [in:] Malindzak D. (ed.), Teória logistiky, 2007.

Manling F., Urban P., Dynamické zlepšování výrobnich procesư pomocí počitačové simulace, „Ekonomika a Management", No 3, 2001. 
Robinson S., Successful Simulation - A Practical Approach to Simulation Projects, McGraw-Hill Co., 2001. www.humusoft.cz (2008-08-10).

\section{Wykorzystanie metod symulacji w identyfikacii,,wąskich gardeł" w gospodarce zapasami}

\section{Streszczenie}

Postępujaca globalizacja gospodarki światowej coraz częściej prowadzi do tworzenia efektywnych systemów dostaw. Nasilanie się konkurencji wymusza na przedsiębiorstwach stałe ograniczanie kosztów działalności operacyjnej, co prowadzi m.in. do konieczności kontroli nabywanych materiałów oraz pozyskanych $w$ zwiazku z tym informacji. Celem artykułu jest opis jednego ze sposobów ograniczania problemów w systemie zarzqdzania zapasami. Jest nim komputerowy model symulacji. Przedstawiono możliwości jego wykorzystania $w$ ustaleniu ,, waskich gardet" w gospodarce zapasami. Założeniem pracy jest przedstawienie założeń tworzonego modelu oraz jego znaczenia w zarzadzaniu kosztami dostaw. Artykut jest opracowaniem powstatym $w$ trakcie realizacji zadania badawczego o numerze MSM 6046137306. 